\title{
FINANCIAL REPRESSION AND CAPITAL MOBILITY: WHY CAPITAL FLOWS AND COVERED INTEREST RATE DIFFERENTIALS FAIL TO MEASURE CAPITAL MARKET INTEGRATION
}

Michael P. Dooley Menzie Chinn

Working Paper 5347

\section{NATIONAL BUREAU OF ECONOMIC RESEARCH 1050 Massachusetts Avenue Cambridge, MA 02138 \\ November 1995}

This paper is part of NBER's research program in International Finance and Macroeconomics. Any opinions expressed are those of the authors and not those of the National Bureau of Economic Research.

() 1995 by Michael P. Dooley and Menzie Chinn. All rights reserved. Short sections of text, not to exceed two paragraphs, may be quoted without explicit permission provided that full credit, including $\odot$ notice, is given to the source. 


\title{
FINANCIAL REPRESSION AND CAPITAL \\ MOBILITY: WHY CAPITAL FLOWS AND \\ COVERED INTEREST RATE \\ DIFFERENTIALS FAIL TO MEASURE \\ CAPITAL MARKET INTEGRATION
}

\begin{abstract}
Required reserves on banks' deposit liabilities have been utilized by both industrial and developing countries to discourage and sterilize international capital flows. In this paper we utilize an open economy macro model incorporating bank credit to evaluate this policy. The model suggests that high levels of reserve requirements are a perverse policy tool in that they amplify the effects of foreign monetary shocks, but changes in reserve requirements can insulate a repressed financial market from international financial shocks. The model also suggests that traditional measures of capital mobility such as interest parity conditions or the scale of gross private capital flows are of no value in assessing the openness of repressed financial systems.
\end{abstract}

Michael P. Dooley

Department of Economics

University of California, Santa Cruz

Santa Cruz, CA 95064

and NBER
Menzie Chinn

Department of Economics

University of California, Santa Cruz

Santa Cruz, CA 95064 


\section{Introduction}

The resurgence in private international capital flows to and from emerging markets since 1989 has raised important questions for economic management. Liberalization of both domestic financial markets and reduction in barriers to international capital flows have called into question the compatibility of fixed, or highly managed, exchange rates and independent monetary policies. For many developing countries the welfare implications of sequencing of reforms in domestic and international financial markets has also been an important issue.

The scale of private capital inflows to emerging markets in Asia and Latin America has been similar but the economic effects on the recipient countries has not been nearly as uniform. In some cases private capital inflows fueled consumption and investment booms and had an immediate impact on real exchange rates, imports and the trade balance. The recent crisis in the Mexican financial system and the sharp downturn in investment and economic growth has again focused attention on the appropriate policy response to capital flows.

It seems clear in retrospect that the "problems" associated with international capital movements spring from the aggregate spending decisions financed by injections of net foreign savings. Since domestic financial intermediaries often dominate the allocation of credit in emerging markets a more careful evaluation of the economics of financial intermediation in different countries might hold the key for understanding the very different effects of capital flows. An interesting policy issue has been renewed interest in direct controls over capital movements motivated in part by doubts about the ability of domestic financial intermediaries to efficiently allocate net foreign savings.

Dooley, Frankel and Mathieson (1987) conjectured that incomplete arbitrage within national financial markets might account for the fact that nonfinancial developments in some countries appear to be insulated from international capital markets even though domestic markets for a narrow class of financial assets are tied to similar foreign markets through interest arbitrage.

"If by capital mobility one means that the tendency of investors to equalize expected rates of return on a subset of liquid, short-term, default free, assets denominated in different currencies or issued by residents of different countries, then there is little doubt that capital is mobile among the major industrial countries. This definition of capital mobility, however is of limited value. It is analogous to measuring the degree of integration of international goods markets by noting that prices (measured in a common currency) are equalized for a subset of goods. There certainly are many agricultural and mineral commodities for which this condition holds quite strictly. It is clear, however, that this condition tells us nothing about the tendency of prices of goods in general to be 
equalized across countries. In fact, this more interesting purchasing-power-parity measure of "goods mobility" has failed to hold in recent years. The key to this more general condition is that within countries the relative prices of goods change by substantial amounts and with no apparent tendency to return to their original levels." pp. 522-23

More recently Fry (1993) and claassen (1993) have argued that poorly developed and highly regulated domestic financial markets in some Asian developing countries explains their ability to "sterilize" capital inflows. The purpose of this paper is to develop a formal model for this conjecture and to begin to confront the data to see if some countries in Asia might $f$ it the model.

The model developed below suggests that in the presence of financial repression conventional tests of capital mobility do not measure the exposure of the economy to shocks from international credit markets. In repressed systems constraints on foreign borrowing by nonfinancial firms imply that the management of reserve requirements can be "effective" in insulating the domestic economy from external financial shocks even in cases where "large" private capital flows insure that covered yields on domestic bank deposit rates are equal to foreign interest rates. The assumption that drives the results is that nonbank residents are unable to bypass the domestic bank loan market. This, of course, is subject to empirical verification.

The model shows that under plausible assumptions reserve requirements are "effective" in distorting domestic lending rates and spending decisions. The distortion, however, is not the one that policy makers may have in mind. The interesting result is that high fixed levels of reserve requirements magnify the effects of a change in foreign interest rates both on the magnitude of private capital flows and on the domestic interest rates most likely to influence spending decisions of residents. Thus, high reserve requirements do not provide "insulation" from changes in international interest rates". Nevertheless, changes in the level of reserve requirements can completely insulate domestic spending decisions from the effects of changes in foreign interest rates. This is the case even though the magnitude of private capital flows are further magnified by change in reserve ratios. In short, neither the traditional measures of covered interest differentials nor the magnitude of private capital flows is a useful measure of the openness of the economy to foreign monetary shocks.

1 It is sometimes argued that high reserve requirements provide liquidity to the domestic banking system in the event of a capital outflow. our model suggests that high reserve requirements magnify capital inflows and outflows equally. The effect of changes in foreign interest rates on other important economic variables is independent of the scale of gross capital flows. 
II Money and credit Transmission Mechanisms

In this section we explore the implications of distortions in domestic credit markets. In a very broad sense we are interested in the "degree of capital mobility" that links the economies of emerging markets with the rest of the world. However, it is argued below that the conventional tests of capital market integration may not be informative in evaluating economic interdependence among countries with very different domestic financial markets.

The transmission mechanism

The standard model that motivates econometric tests of interdependence is based on a model of the transmission mechanism for monetary policy that emphasizes the demand for and the supply of banks' monetary liabilities. This emphasis appears to be justified for industrial countries but it is argued below that the institutional arrangements that make this approach natural in industrial countries may be entirely absent in some of the emerging markets that are of interest in this paper. For these countries a transmission mechanism that emphasizes the demand for and supply of bank credit may be more useful in evaluating interdependence.

Frankel (1994) argues that the traditional model does offer a coherent explanation for the ability of some countries to "sterilize" the effects of capital inflows on the domestic money supply. Countries that sterilize successfully are defined as those in which money demand and spending decisions are little affected by changes in short-term interest rates. In the traditional Mundell Flemming model this is summarized by inelastic IS and IM curves. It follows from this model that changes in foreign interest rates will have limited influence on the central bank's control of the domestic money supply even if the domestic interest rate is tied to the foreign rate.

An obvious feature of this framework is that monetary policy is summarized by the market clearing conditions for money which depends, in turn, on a representative interestbearing $f$ inancial asset. It is recognized that there are many interest rates in the economy, but differences in the term to maturity structure are easily explained by the term structure in international markets, while differentials due to risk return tradeoffs, taxes, and other institutional features may be substantial but are not sensitive to the policy tools available to the authorities.

our conjecture is that these are valid assumptions for the industrial countries and for developing countries in which domestic banks are easily bypassed through capital flight and nonbank financial intermediaries. In these financial markets, integration of the market for short-term traded assets such as bank deposits or government securities is sufficient to insure that, with fixed exchange rates, monetary policy actions in industrial countries are quickly transmitted to all important financial markets, and in turn, to goods markets. Moreover, the institutional structure of domestic financial markets in these countries suggests that the transmission mechanism for 
monetary policy involves the demand for banks' monetary liabilities and the opportunity cost of holding money. Not surprisingly, this is the transmission mechanism modeled in the standard Mundell-Flemming framework.

For emerging markets with much less developed domestic financial markets, but markets that residents cannot easily bypass, this might be an incomplete model for the transmission mechanism. We argue below that institutional arrangements in several developing countries in Asia strongly favor the credit view of the transmission mechanism. In turn, this suggests that integration of a traded security market such as bank deposits or treasury bills may not imply that foreign monetary policy is transmitted to other financial markets that influence goods markets in these countries. Capital controls might fail to isolate domestic bank deposit markets but shocks to this "traded asset" market may not be transmitted to other domestic financial and goods markets.

We exploit an analytic framework developed in Bernanke and Blinder (1987) to evaluate the "credit view" of the monetary transmission mechanism in industrial countries. This literature stresses asymmetric information about borrowers, and, in some models, about financial institutions, as a source of credit market imperfections. ${ }^{2}$ Such imperfections, in turn, imply that the supply of bank credit might be crucial for aggregate spending decisions. If bank credit, in turn, is constrained by the supply of banks' reserves, manipulation of the supply of reserves by the central bank through open market operations, discount borrowing, or changes in reserve requirements can influence spending decisions through the "credit channel".

Money and credit in industrial countries

The empirical relevance of the credit view of the transmission has proven quite limited in the context of the industrial countries. There are at least two reasons for this result. In the United states, for example, firms can bypass the banks by issuing commercial paper, bonds and other direct liabilities that are independent of the supply of bank credit. Even in countries where firms access to alternative sources of credit is limited, the institutional setting in well-developed markets is such that the supply of bank credit is unlikely to be constrained by the supply of bank reserves. Bank credit might be quite special to many borrowers so that changes in the availability of bank credit generated, for example, by changes in regulatory policies or the capital base of commercial banks might affect spending, but the usual monetary policy tools do not directly constrain bank lending. Empirical test reported below, for example, suggest that bank credit is an important determinant of spending decisions in Japan. But this does not mean that monetary policy is transmitted to the economy by changes in bank credit. The reason is that banks in industrial countries have developed nondeposit sources of funds that are very close substitutes

2 See Gertler (1988) for a review of this literature. 
for the liabilities of governments and nonfinancial firms. Moreover, as documented by a recent study of reserve requirements in industrial countries by the Bank of Japan (1995), authorities in industrial countries have reduced reserves against nonmonetary liabilities of banks in recent years, in most cases in an effort to maintain banks' competitive positions in credit markets. It follows that the supply of bank credit is not constrained by the supply of bank reserves.

The institutional setting in industrial countries favors the "money is special" view. Monetary liabilities of banks are likely to be constrained by the supply of bank reserves since reserve requirements on monetary liabilities are typically much higher as compared to banks' nonmonetary liabilities such as CDs and other nondeposit liabilities. Moreover, at least in the United states, reserves are applied to the monetary liabilities of nonbank financial intermediaries. The Federal Reserve for example imposes reserve requirements on monetary liabilities regardless of the issuing institution. It follows that the supply of central bank reserves is closely related to the supply of monetary liabilities. The supply of money, in turn, affects spending decisions either through interest rates or more directly through wealth effects.

Money verses credit in emerging markets

The institutional arrangements that would make the credit view more likely to be important are found in many emerging markets. Financial markets in such economies are typically dominated by commercial banks. Moreover, financial repression in these banking markets is an important source of revenue in many cases. As shown in Drazen (1989) the key to this revenue is the imposition of reserve requirements on all bank liabilities. This would normally encourage the growth of nonbank financial intermediation so a natural extension of this policy is to discourage development of domestic nonbank financial intermediaries and capital controls that discourage nonbank borrowing in foreign markets.

Firms may also find it difficult to borrow from offshore institutions because it is difficult for the firm to offer lenders credible information about their financial condition. Asymmetric information is a well known problem that limits lenders' ability to distinguish between good and bad credit risks. In most cases disclosure of financial information is not mandated by law as a condition for access to equity or bond markets, traded equity is limited to a few of the largest firms and accounting standards are less commonly applied. This presumably makes the information generated by a relationship with a domestic bank, that at least has information about the firms and the firms' owners transaction, valuable and difficult to replicate.

In contrast to banks in industrial countries, nonmonetary liabilities of banks often carry reserve requirements that are about the same as those on monetary deposits. Moreover, in some cases even higher differential reserve requirements have been imposed on increases in nonresident and resident 
deposits. These differential reserve requirements are often a part of capital control programs designed to discourage capital inflows. As discussed below these institutional arrangements fit the requirements of the credit view quite closely.

A key assumption that may not fit emerging markets in Latin America is the ability of residents and nonresidents to avoid the repressed financial market. The scale of capital flight from Latin American countries is strong evidence that attempts to isolate and tax domestic financial markets have been circumvented by the private sector. Moreover, as documented by Rojas-Suárez and weisbrod (1995) domestic nonbank intermediation has grown rapidly in Latin American countries that have maintained high reserve requirements so that marginal deposit reserve ratios are quite low. statistics on capital flight suggest that foreign intermediation is less of a problem in most Asian countries. While the growth of nonbank intermediation is much more difficult to measure in countries where it is discouraged by the government, it seems likely that this is also less of a problem in Asian developing countries. spiegel (1995) develops a model similiar to that used in this paper and argues that reserve requirements have generated domestic nonbank intermediation in Korea and other Asian developing countries. While we agree that the incentives are important and will eventually undermine financial repression, our reading of the data is that this process is just beginning in several important emerging markets. In Korea, for example, nonbank intermediaries have grown but are subject to the same reserve requirements as the banks.

A model of a partially open financial system

The basic model is an adaptation of Bernanke and Blinder (1988) and Romer and Romer (1990). We first consider a monetary sector in isolation in that the real and nominal income is predetermined. The financial system is the simplest possible with a banking system. The exchange rate is fixed. Banks hold three assets, reserves (R), loans (L) and domestic government securities (B). Banks issue two liabilities, domestic demand deposits (M), henceforth "money", that carry a legal reserve requirement of $(t)$ and nonmonetary deposits (D), henceforth "deposits", that carry a legal reserve requirement of ( $\left.t^{\prime}\right)$. Firms issue bank loans only. They cannot issue bonds to other residents or to nonresidents. The absence of a nonbank bond market reflects asymmetric information and regulatory constraints. The central bank issues reserves for the banks ( $R$ ), its assets are domestic government securities (B) and foreign reserve assets (R*). The relevant balance sheet constraints are

$$
\begin{aligned}
& R=t M+t^{\prime} D \\
& L=(1-t) M+\left(1-t^{\prime}\right) D
\end{aligned}
$$

We assume the supply of loans is positively related to the loan interest rate, $\rho$, and inversely related to the deposit rate, $r$. 
The spread between the loan rate and the deposit rate is a function of the marginal cost of funds to the banking system, that is, min $r /\left(1+t^{\prime}\right)$ if there are deposits or $r /(1+t)$ if there are not $^{3}$, and the marginal cost of obtaining information concerning the quality of new loans offered by the private sector. The demand for loans is inversely related to $\rho$ and positively related to income $(Y)$.

In order to sharpen the distinction between the model and the standard model we assume that foreign bonds, domestic government bonds and deposits are perfect substitutes for both residents and nonresidents. Given the credibly fixed exchange rate this means that the domestic deposit rate is always equal to the foreign interest rate. Residents' demand for money is

$$
\mathrm{Md}=\mathrm{M}(\mathrm{r}, \mathrm{Y})
$$

The policy shock we are interested in is a change in the foreign interest rate. Holding income constant we can solve this system for the change in reserves as a function of the change in the foreign interest rate as follows

(4) $d R / d r^{*}=\left[t^{\prime}\left(L_{p} * \rho_{r^{*}}+L_{r^{*}}\right)+\left(t-t^{\prime}\right) M_{r^{*}}\right] /\left(1-t^{\prime}\right)$ Where subscripts are partial derivatives.

Four implies that the change in the demand for bank reserves following a change in the world interest rate depends on the structure of reserve requirements, the response of the bank loan rate, the elasticity of the loan demand to the loan rate and the bond rate, and the interest elasticity of money demand.

These relationship are summarized in Figure 1. The horizontal balance of payments curve, BP, reflects the assumption that any current account imbalance can be financed of the world rate of interest. A fall in the world interest rate shifts $B P$ down to $B_{1}$. Holding income at $X_{0}$, the $L M$ curve must shift to $\mathrm{LM}_{1}$. The slope of the LM curve determines the change in money demand and supply consistent with the new world interest rate. The $C C$ curve must also shift to $C_{1}$. The slope of the CC curve determines the change in the demand and supply of banks' nonmonetary liabilities, and this in turn also changes the demand and supply of reserves depending on the reserve requirement against nonmonetary liabilities. If the central bank was entirely passive, the increase in the demand for bank reserves would be generated by unsterilized intervention in the form of purchases of international reserve assets by the central bank.

Several special cases are immediately interesting. First, if time deposits do not carry reserve requirements, or more generally if banks can issue bonds that are free of reserve requirements, the model collapses to the traditional $M-F$ model in that the change in the demand for reserves depends entirely on the interest elasticity of the demand for money and the reserve requirement on money balances. In terms

${ }^{3}$ We assume that monetary deposits cost the bank $r$ even if the nominal return paid to depositors is zero. 
of Figure 1 a decline in the foreign interest rates generates a shift in the BP curve; the supply of bank reserves must rise to match the increase in money demand implied by the slope of the LM curve times the reserve requirement. The CC curve must also shift down so that the equilibrium demand for bank loans rises but this does not alter the demand for reserves.

Next consider the interesting case in which the government attempts to "sterilize" the domestic market for bank reserves by imposing a 100 percent marginal reserve requirement against foreign deposits. In this case the change in reserves is infinity large as (1-t') $\rightarrow 0$. This must be true because any change in money or loan demand is not matched by a change in excess reserves. This clarifies the assumption that bonds are perfect substitutes in the model. Sterilized intervention cannot alter the equilibrium interest rate on the traded asset.

Finally, the case of greatest interest is that in which reserves on deposits are less than one hundred percent but equal to or greater than reserves on monetary liabilities. Referring again to Figure 1, the shift in the LM curve does not increase the demand for reserves since the shift from interest bearing deposits to monetary deposits decreases the demand for reserves. The increased demand for reserves comes from the shift in the CC curve, that is the bank loan market.

As can be seen from (4) the slope of the CC curve depends upon the reserve requirement $t$ ', the elasticity of the loan rate to the deposit rate and the elasticity of loan demand to the loan rate. For simplicity we assume that loan demand is not sensitive to the bond rate because borrowers cannot issue bonds.

The difficult question is how the spread between the deposit rate and the loan rate should be modeled. Romer and Romer (1990), for example, assume that the spread decreases as $r$ declines. This makes sense because the implicit tax imposed by a noninterest bearing reserve is increasing in $r$, that is, the tax per dollar of loan is $r /\left(1-t^{\prime}\right)$. Thus, higher nominal interest rates imply a larger absolute spread and falling interest rates would be associated with a fall in the spread. It follows that the higher the reserve requirement the greater is the change in the loan rate in response to a change in the world interest rate. This means that high reserve requirements do not help insulate the domestic economy from the transmission of shocks from international capital markets.

This conclusion might be tempered by changes in other determinants of the loan deposit spread. For example, it could be argued that the spread increases when r* falls because marginal increases in loan volume increase risk or monitoring costs. It is plausible in repressed financial markets that banks have a set of existing relationships with firms that provide the individual bank valuable inside information concerning firms' profitability. Expanding loans to existing customers increases the concentration of risks to the bank's capital inherent to its existing customer base. In developing countries, diversification is often quite limited in that existing bank borrowers are often concentrated in a few state-owned firms and one or two export industries. 
This argument for insulation assumes that the risk of default actually falls on bank capital and this, in turn, assumes that bank capital is positive. In countries where financial reform begins with negative net worth banks this is not a good assumption. In such cases we would expect to see a relatively large response in the supply of bank credit to a fall in international interest rates.

The bank can also expand its lending base by seeking new customers but in this case the marginal loan rate must cover the fixed costs of identifying firms that are similar in terms of risk and return to the set of existing borrowers. In either case a rise in the volume of bank credit is associated with an increase in the loan deposit spread.

Another possibility is that loan rates are effectively controlled by the government. In this case the bank is constrained from offering lower loan rates as deposit rates fall, and so the supply of bank credit is not at all affected by changes in deposit rates. Such administered interest rates are much more likely to be effective in emerging markets where firms cannot go around the banks into the bond market. Moreover if there are only a few large banks they might be quite content to exploit the monopoly profits generated by the government's price fixing arrangement.

In summary, the tax effect associated with high reserve requirements would tend to magnify the transmission of a change in the foreign interest rate to the domestic bank loan rate. Other plausible stories about how lending rates respond to changes in deposit rates suggest that lending rates and ultimately bank credit might respond very little to changes in the cost of funds to the banks.

The goods market

We now consider the response of the system to a change in foreign interest rates when income is free to adjust. It is clear that the elasticity of the cc curve with respect to the world interest rate holding the loan rate constant is likely to be very low in a repressed system. Given our assumption that domestic deposits and domestic bonds are perfect substitutes for foreign bonds, "the" interest rate that appears in Figure 1 can be thought of as the domestic deposit rate. Changes in this rate, other things equal, might affect savings decisions but because of the offsetting income and substitution effects the sign of the effect is ambiguous.

If changes in the deposit rate are associated with changes in the loan rate, the cc curve will shift in response to a fall in the international interest rate. We argued above that the loan rate might react slowly, partially, and perhaps not at all to changes in the deposit rate. Thus, the shift in the CC curve depends on the loan supply behavior of banks and the demand for loans by firms.

Consider again the conventional $M-F$ framework. In this model the response of the real economy is captured by the slope of the IS curve. As the world interest rate falls domestic investment rises and the demand for money rises because of the increase in nominal GDP. Clearly capital mobility means that the government must increase the monetary 
base by a fraction of the increase in the demand for money. Now consider the complete model with the credit market included. Again the fall in the world interest rate shifts the BP curve down. But the CC curve shifts to the right depending on the response of the loan rate. If there is an effect on the real economy it must come largely through a shift in the CC curve. If this shift is small for the reasons discussed above, the transmission of the foreign shock to the real sector is also small.

The change in international reserves in response to a change in the foreign interest rate is now

(5) $\mathrm{dR} / \mathrm{di} *=\left[\mathrm{t}^{\prime}\left(\mathrm{L}_{\mathrm{p}} \rho_{\mathrm{r}}{ }^{*}+\mathrm{L}_{\mathrm{y}} * \mathrm{Y}_{p}{ }^{*} \rho_{\mathrm{r}}{ }^{*}\right)\right.$

$$
\left.+\left(t-t^{\prime}\right)\left(M r+M y * Y_{\rho} * \rho r^{*}\right)\right] /\left(1-t^{\prime}\right)
$$

Capital controls in the form of reserve requirements on nonresident deposits have two interesting effects. First, they imply a larger private capital inflow and change in reserves is associated with a given disturbance in the foreign interest rate. Second, they tend to increase, other things equal, the change in the bank lending rate and therefore the real effect of the foreign interest rate change.

Why do countries employ reserve requirements that appear to be counterproductive in that they magnify changes in international reserves? So far we have focused on the effects of a given reserve regime as world interest rates change. But what is the effect of a change in the differential reserve? Suppose for example that a fall in the world interest rate and the resulting capital inflow induces the government to raise the reserve requirement. The impact effect on the demand for loans is

(6) $\mathrm{dL} / \mathrm{dt} \mathrm{t}^{\prime}=\mathrm{L}_{\mathrm{p}} * \rho_{\mathrm{t}}$.

which is negative.

Assuming that $t$ remains equal to $t^{\prime}$ the impact effect on reserves is

(7) $\mathrm{dR} / \mathrm{dt} \mathrm{t}^{\prime}=\left(\mathrm{L}_{p} * \rho_{\mathrm{t}}\right) /\left(1-\mathrm{t}^{\prime}\right)$

The immediate effect is to reduce the capital inflow and the gain in reserves. But other things equal the cost of bank loans clearly rises. In effect the domestic borrower must pay the tax on the marginal foreign money. This has the effect of discouraging the transmission of the real effects of the interest rate change. So evidently a constant high reserve requirement has perverse effects. But an endogenous reserve requirement policy that increases reserve ratios as world rates fall succeeds in insulating the domestic loan market from the external shock. The "sterilization" policy succeeds not because it discourages international capital mobility but because it discourages domestic financial intermediation.

There is an interesting trade-off here. A higher $t$ ' means a smaller shift in the CC curve follows a change in the foreign interest rate. The analysis makes it very clear that a high marginal reserve requirement against foreign deposits generates a meaningless (as long as the fixed exchange rate regime lasts) private capital inflow which is offset by a change in international reserves of the government. The high reserve requirement also explains the often mentioned stylized 
fact that real loan rates in the capital inflow countries are high. There have been a number of competing stories for this but this model suggests that financial repression can help explain these high real rates.

There are also the seeds of a banking system crisis in this model although a full exploration is beyond the objectives of this paper. The intuition is that the increasing tax of the capital controls falls on domestic loan rates. In turn, if the banks and the regulators are not careful only high risk borrowers will accept these terms. The key here is that we have set the stage so that capital controls work not through distorting traded asset returns as is typical in the standard model, but instead through distorting the cost of domestic financial intermediation. This distortion might limit the impact on domestic spending decisions as we have discussed here. But if the incentive for banks is to survive with negative net worth the same policies could fuel a speculative boom that more often than not will end in a bust.

Empirical relevance of the model

The conventional model suggests that capital controls are effective if they drive a wedge between "the" international interest rate and "the" domestic interest rate. Dooley and Isard (1980) document the use of reserve requirements and other controls over capital inflows by Germany from 1970-1974 and shows that controls generated substantial covered interest rate differentials between onshore and offshore bank deposits over this period. The ability of control programs to generate differences in yields on short term investments such as bank deposits or government securities remains the standard test for the effectiveness of controls in insulating economies from the effects of foreign interest rates.

Similar tests for the emerging markets of interest in this paper suggest that their domestic credits markets are highly integrated with international capital markets. The evidence for this traditional measure of capital mobility or capital market integration is presented in Chinn and Dooley (1995). Tables 1 and 2 reproduce these results. Countries included in this sample are those for which data on forward exchange rates are available. Since the existence of forward exchange markets is a good indicator of the development of financial markets it is not surprising that covered interest parity holds in most cases quite closely. A recent exception is Malaysia where extensive controls over capital inflows allowed domestic interest rates to remain well above covered returns on similar dollar assets for a few months.

For countries without well developed forward exchange markets the presumption that even short term asset yields are equalized is less obvious. Haque and Montiel (1990) develop an empirical test for developing countries for which market clearing domestic interest rate data is not available. This research utilizes an instrumental variable approach to control for the endogeneity of the observed monetary base. The authors conclude that the degree of capital mobility among developing countries is quite high and argue that this 
indicates that the pervasive controls over capital flows in place in most of the countries studied provide little scope for an independent monetary policy.

Dooley and Mathieson (1994) extend this model in order to test for changes in the degree of capital mobility over time. They also find that capital is quite mobile for countries that have extensive control programs and that, in most cases, this degree of mobility has increased over time. In general, this line of research suggests that control programs in developing countries have been of limited effectiveness.

other authors using similar techniques have reported mixed results. Reisen and Yeches (1991) utilize curb market rates as a measure of effective domestic interest rates and find that capital mobility remained roughly constant for a group of Asian countries while Faruqee (1991) finds that integration between developing countries in Asia and Japan seems to have increased in recent years.

Each of the papers discussed above attempts to measure a counterfactual monetary base that the authorities are assumed to set for an extended time period. However, the observed change in the domestic part of the monetary base is some combination of the exogenous policy change and the response during the time period studied to offsetting private capital flows. Since the response to a policy induced change in the monetary base can be literally instantaneous, it is difficult to identify the policy induced part of observed changes short of developing a complete model of government behavior. It appears to be the case that different techniques for dealing with the endogenous nature of the regressors have important consequences for the results of these studies.

our interpretation of the evidence is that domestic markets for short term financial assets in emerging markets are highly integrated with similar international markets. Thus, it seems sensible to retain this assumption in attempting to understand the effects of changes in international interest rates and other external financial shocks.

The next important empirical issue is the degree of integration of domestic loan markets in emerging economies with international loan markets. This empirical issue is obscured by the fact that data on bank lending rates is difficult to interpret. Banks may have several lending rates to different types of customers and different banks have different lending rates at a point in time. Thus, data on bank lending rates is typically an average of a periodic survey of new or all outstanding loans. Moreover, because the bank relationship is complicated and valuable to both sides, neither banks nor their customers are anxious to reveal the actual terms of their lending agreements. Certainly in cases where government regulations specify a loan rate structure it would be very surprising to see anything but the legal requirements reported to the central bank.

Nevertheless data reported in in Chinn and Dooley (1995) and reproduced in Figure 2 show that there are clear differences in the behavior of loan rates and of loan open market rate spreads. This data suggests to us that the 
transmission of changes in money market rates to bank lending rates is much more obvious in the industrial countries as compared to the emerging markets. It would appear that there is at a minimum some scope for government policies designed to affect the loan deposit spread.

In order for the model proposed above to be relevant two additional factors must be at work. The first is that the country must impose reserve requirements on a wide range of bank liabilities. Second, bank credit must have a measurable and independent effect on spending decisions.

None of the industrial countries is likely to meet these requirements. As documented in Bank of Japan (1995) the industrial countries have turned away from reserves on nontransactions accounts at banks in most cases because they injure the competitive positions of banks relative to other financial intermediaries.

As shown in Table 3 this trend toward lower reserve requirements is not evident for the emerging economies. The table shows data for the ratio of bank reserves to total deposit liabilities. Four countries, Korea, Indonesia, Malaysia and the Philippines seem good candidates for our model in that average reserve requirements are quite high relative to the industrial countries. Moreover, as described in Folkerts-Landau et al (1995) Malaysia and Korea actively used reserve policies to offset capital inflows after 1989 .

The final necessary linkage is between bank credit and aggregate spending. Table 4 presents findings on the relationship between quarterly changes in imports and lagged changes in bank credit, the real exchange rate and income. For developing countries we are particularly interested in imports as a category of spending because high quality quarterly data is available for a wide range of countries. Moreover imports are often found to be quite sensitive to investment and consumer durable expenditures that are most likely to be constrained by conditions in financial markets.

The regression estimates for Japan and Philippines strongly support the view that bank credit is an important determinant of spending decisions and the money is not. The Korean data suggest that bank credit is important although the estimate is not significant at conventional levels. Results for Indonesia suggest that money is more important than bank credit although bank credit does have a positive independent effect.

Consistent with our expectations the highly developed and liberalized domestic financial markets seem to show little independent effect of changes in bank credit. In our sample these cases include Australia, Canada, New Zealand and singapore. Data for two important countries in our sample, Taiwan and Malaysia, are clearly discouraging in that credit does not have the expected impact on spending decisions. For these countries we were forced to use total domestic credit rather than bank credit as the right hand side variable and this may account for the results.

Table 5 shows the relationship between quarterly changes in income, in some cases estimated from changes in industrial production, and lagged changes in money or bank credit, 
income, and the real exchange rate. The estimated effects of changes in money and credit are quite similar to those discussed for imports above. For this reason we conclude that future research is justified in focusing on readily available data for imports rather than the somewhat more problematic data on income or output.

Finally, Table 6 shows the relationship between quarterly changes in investment and lagged values of changes in bank credit or money, income and the real exchange rate. These results also suggest that investment is affected by money or credit in a very similar manner as imports. Once again, Japan and Korea seem to fit the credit is important model while Australia and Canada seem to fit the money is important model.

\section{Conclusions}

The evidence presented above is far from conclusive. More careful modeling of the financial systems of these countries with the credit view of the transmission mechanism is needed in order to understand the relationship between internal and external shocks to the bank loan market. But there does seem to be a good case for taking a careful look at the transmission of foreign shocks through the domestic banking system in evaluating these countries' relationship with one another and the rest of the world.

The traditional Mundell Flemming model of a small open economy remains the dominant tool for understanding macroeconomic consequences of capital mobility and capital flows for emerging markets. There is a good chance, however that the microeconomics of financial intermediation in repressed financial systems might also yield important insights concerning the effects of international economic integration.

In this paper we modify a well known closed economy model in order to study the effects of market imperfections that make bank credit "special" and that might be very important for emerging markets. The model helps clarify the effects of a reserve requirements as a policy tool that has been used historically by industrial countries and recently by developing countries to discourage capital flows. Results that mimic some of the important economic regularities for emerging markets emerge from the model.

First, the model is consistent with the evidence that covered interest parity holds on short-term, traded assets. Thus, in the traditional sense this is a model of "perfect capital mobility".

Second, reserve requirements seem to be perverse in that a high level for reserves on nonresident deposits increases the sensitivity of private capital flows, domestic investment and consumption to a foreign monetary policy disturbance. A high level of the reserve requirement also magnifies the change in international reserves generated by a foreign monetary shock and the quasi fiscal deficit associated with sterilized intervention.

Third, although a high level of reserve requirements on bank deposits seems to be counterproductive the model also implies that changes in the level of reserve requirements can 
fully insulate the domestic economy from the foreign monetary policy shock.

The intuitive basis for these results is that monetary policy affects spending decisions through changes in the supply of bank credit. The assumption that bank deposits are perfect substitutes across countries (when exchange risk is covered or the exchange rate is credibly fixed) means that the differential reserve requirement on deposits held by nonresidents is a tax that falls on bank lending rather than the resident or nonresident holds of bank deposits.

The underdeveloped nature of the domestic financial system and asymmetric information implies that resident borrowers cannot avoid this tax by issuing marketable bonds or dealing with foreign or nonbank domestic financial intermediaries. For a given level of reserve requirements, a change in the foreign interest rate generates a more than equivalent change in the bank lending rate. Thus, the credit transmission mechanism is magnified by the capital control. But changes in the reserve requirement change the effective tax rate and can, in principle, be manipulated to neutralize a foreign shock.

Preliminary empirical work suggests that the model may well be useful in evaluating policy options in many developing countries that have maintained repressed domestic financial systems. 


\section{References}

Bank of Japan, Quarterly Bulletin, May 1995.

Bernanke, Ben and Alan Blinder, "Credit, money and aggregate demand," American Economic Review, Vol. 78, No. 2, (May 1988), pp. 435-439.

Browne, Francis X., and Paul D. McNelis, "Exchange Controls and Interest Rate Determination with Traded and Non-Traded Assets: the Irish-United Kingdom Experience," Journal of International Money and Finance, Vol. 9 (1990), pp. 41-59.

Chinn, Menzie and Michael Dooley, "Asia-Pacific Caspital Markets: Integration and Implications for Economic Activity," NBER Working Paper \#5280, September 1995.

Chinn, Menzie D., and Jeffrey A. Frankel, "Financial Links Around the Pacific Rim: 1982-1992," in R. Glick and $M$. Hutchison, eds., Exchange Rate Policy and Interdependence: Perspectives from the Pacific Basin (Cambridge, Massachusetts: Cambridge University Press, 1994), pp.17-47.

Claassen, Emil, "Financial Opening and Monetary Control in Pacific Basin Developing Market Economies: A Comment," in Helmut Reissen and Bernhard Fischer, eds. , Financial opening: Policy Issues and Experiences in Developing Countries, (Paris: organisation for Economic Co-operation and Development, 1993), pp. 165-171.

Dooley, Michael P., and Donald J. Mathieson, "Exchange Rate Policy, International Capital Mobility, and Monetary Policy Instruments," in R. Glick and M. Hutchison, eds., Exchange Rate Policy and Interdependence: Perspectives from the Pacific Basin (Cambridge, Massachusetts: Cambridge University Press, 1994), pp. 68-95.

Dooley, Michael P., Jeffrey Frankel, and Donald J. Mathieson, "International Capital Mobility: What Do Saving-Investment Correlations Tell Us?" Staff Papers, International Monetary Fund, Vol.34, No.3 (September 1987).

Dooley, Michael P., and Peter Isard, "Capital Controls, Political Risk, and Deviations from Interest-Rate Parity," Journal of Political Economy, Vol.88, No.2 (April 1980), pp. 370-384.

Drazen, Allan, "Monetary Policy, Capital Controls and Seigniorage in an Open Economy," in M.de Cecco and A. Giovannini, eds., A European Central Bank?: Perspectives on Monetary Unification After Ten Years of the EMS, (New York: Cambridge University Press, 1989) pp. 13-32.

Fackler, James S. and John H. Rogers, "An Empirical OpenEconomy Macro Model with Credit," Journal of Macroeconomics, vol. 15, No. 2 (Spring 1993), pp. 203-224. 
Faruqee, Hamid, "Dynamic Capital Mobility in Pacific Basin Developing Countries: Estimation and Policy Implications," Staff Papers, International Monetary Fund, Vol. 39, No. 3 (September 1992), pp. 706-717.

Frankel, Jeffrey A., "sterilization of Money Inflows: Difficult (Calvo) or Easy (Reisen)?" Paper presented at conference on Capital Inflows: Size, Nature and Policy Adaptions, Cartagena, Colombia, July 29-30, 1994 .

Fry, Maxwell, "Financial opening and Monetary Control in Pacific Basin Developing Market Economies," in Helmut Reissen and Bernhard Fischer, eds., Financial opening: Policy Issues and Experiences in Developing Countries, (Paris, organisation for Economic Co-operation and Development, 1993), pp. 143-164.

Haque, Nadeem Ul, and Peter Montiel, "Capital Mobility in Developing Countries - Some Empirical Tests," IMF Working Paper 90/117 (Washington: International Monetary Fund, December 1990).

Loungani, Prakash and Mark Rush, "The Effect of Changes in Reserve Requirements on Investment and GNP, " Journal of Money. Credit and Banking, Vol. 27, No. 2 (May 1995), pp. 511-526

Lown, Cara, "Credit-output Link vs. the Money-output Link: New Evidence," Federal Reserve Bank of Dallas Economic Review (November 1988), pp. 1-10.

Mathieson, Donald J., and Liliana Rojas-Suarez, "Liberalization of the Capital Account, Experiences and Issues," IMF Occasional Paper 103 (Washington: International Monetary Fund, March 1993).

Reisen, Helmut, "Macroeconomic Policies Towards Capital Account Convertibility," in Helmut Reisen and Bernhard Fischer, eds., Financial opening: Policy Issues and Experiences in Developing Countries, (Paris: Organisation for Economic Co-operation and Development, 1993), pp. 43-55.

Reisen, Helmut, "Pension Funds, Capital Controls and Macroeconomic Stability," OECD Working Paper Vol. 2, No. 47 (Paris, France: Organization for Economic Co-operation and Development, 1994).

Reisen, Helmut, and Helene Yeches, "Time-Varying Estimates on the Openness of the Capital Account in Korea and Taiwan," Journal of Development Economics, Vol.41, No.2 (August 1991), pp.285-305.

Rojas-Suarez, Liliana and Weisbrod, Steven, "Financial Market Fragilities in Latin America: From Banking crisis Resolution to Current Poloicy Challenges," IMF Working Paper No. WP/94/117 (Washington: International Monetary Fund, October 1994) 
Figure 1

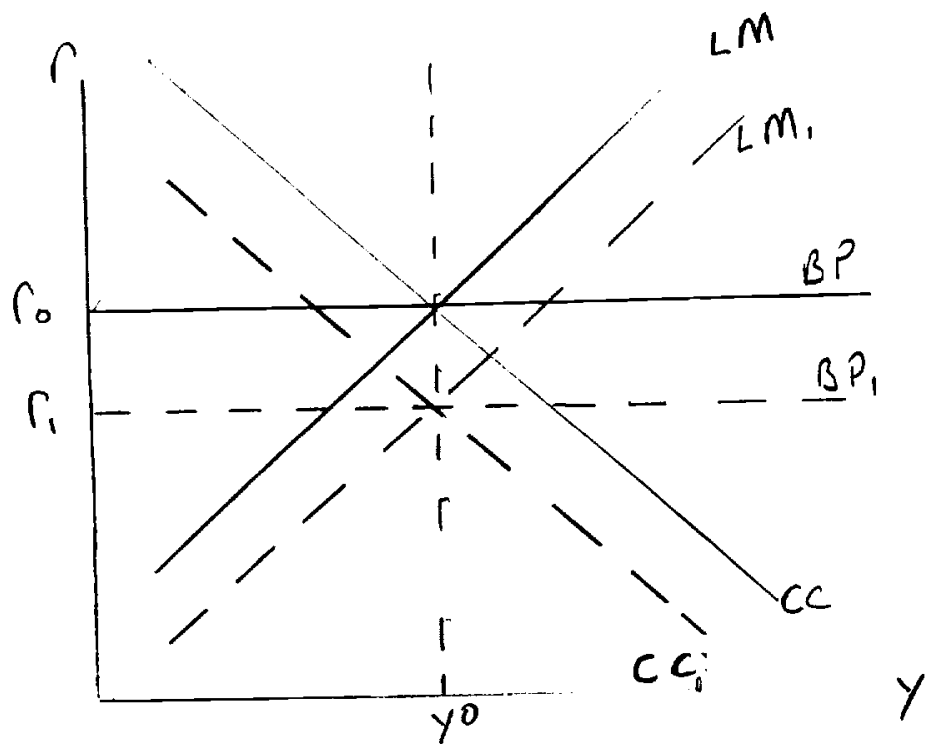


Figure 2

Money Market Loan Interest Rate spreads

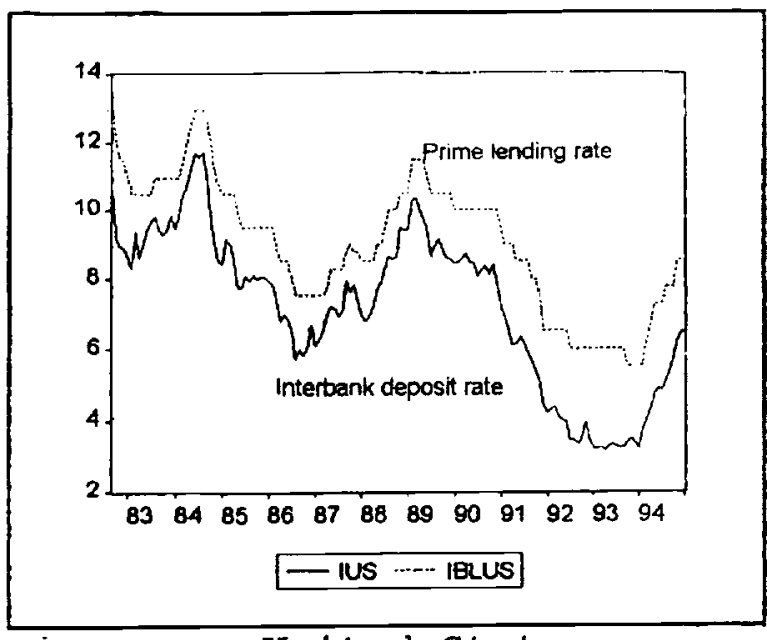

United States

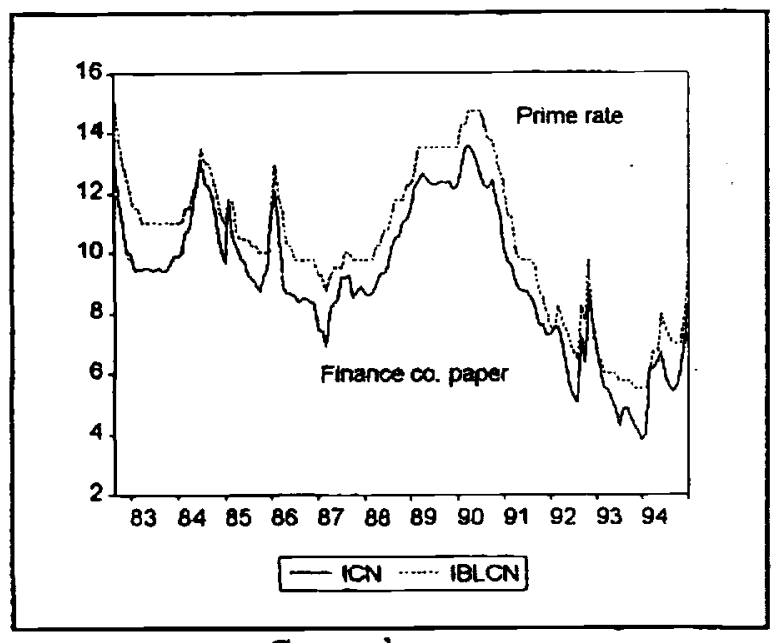

$\because \quad$ Canada

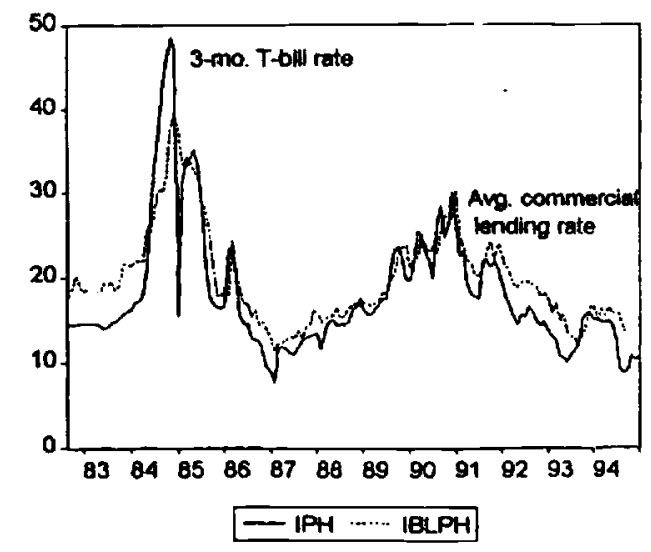

Philippines

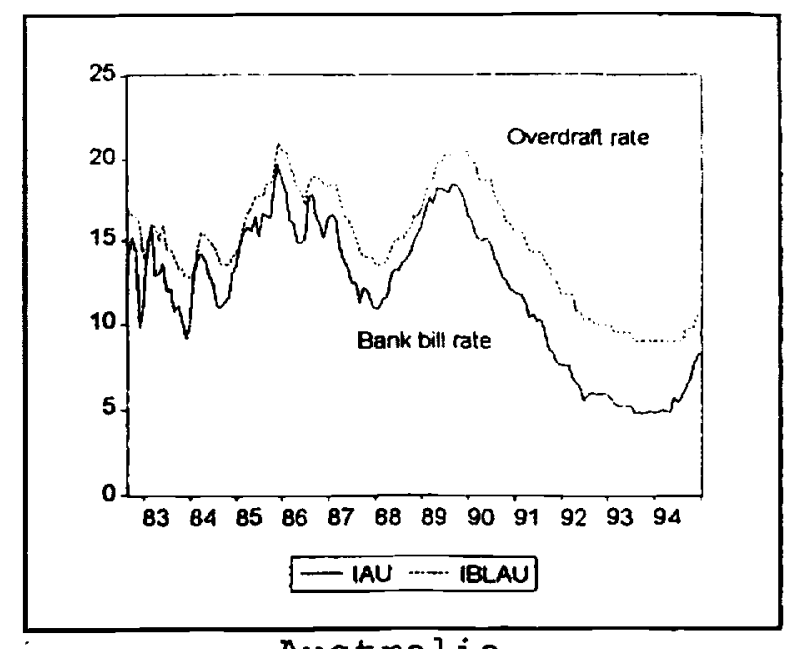

Australia
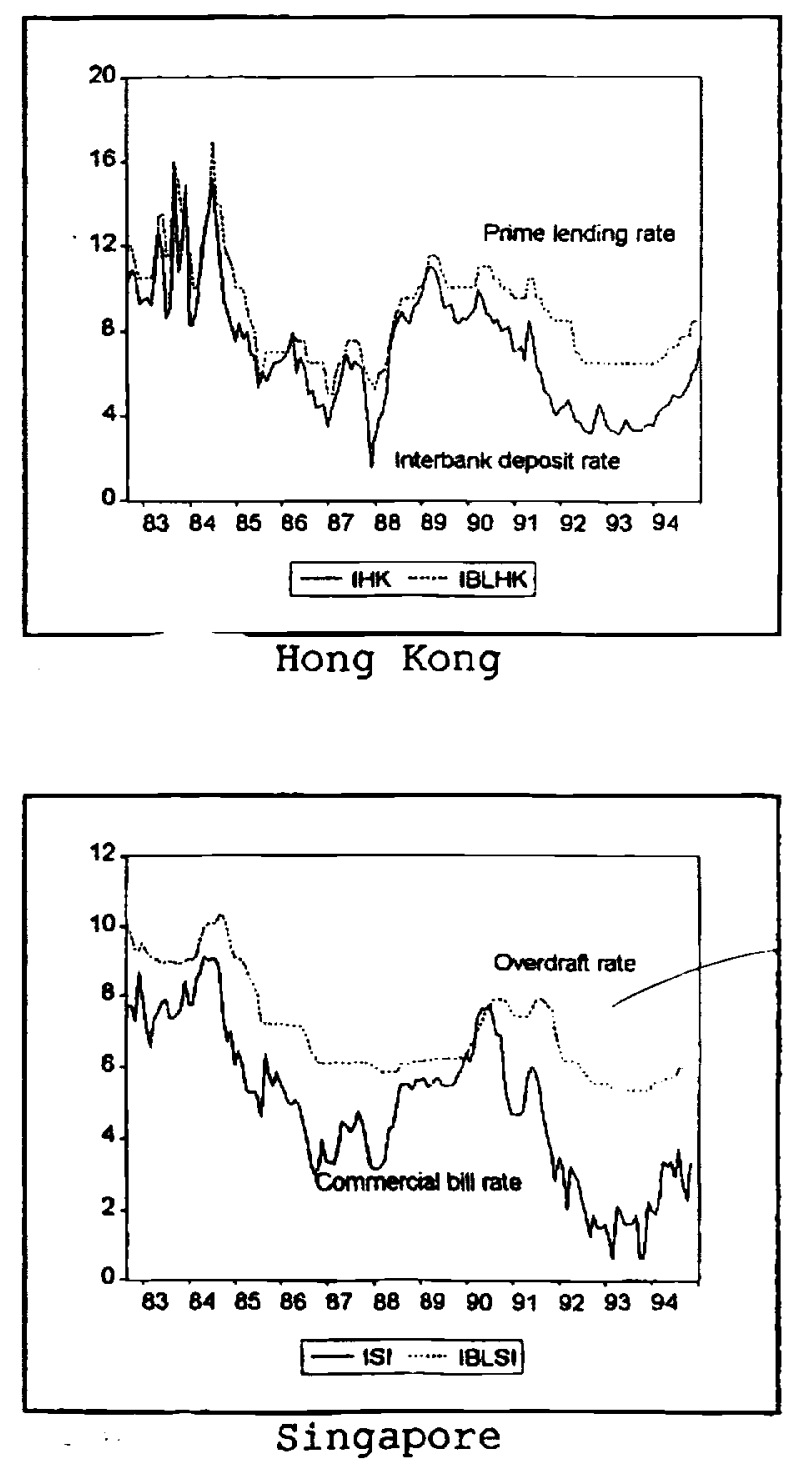
Figure 2 (cont.)
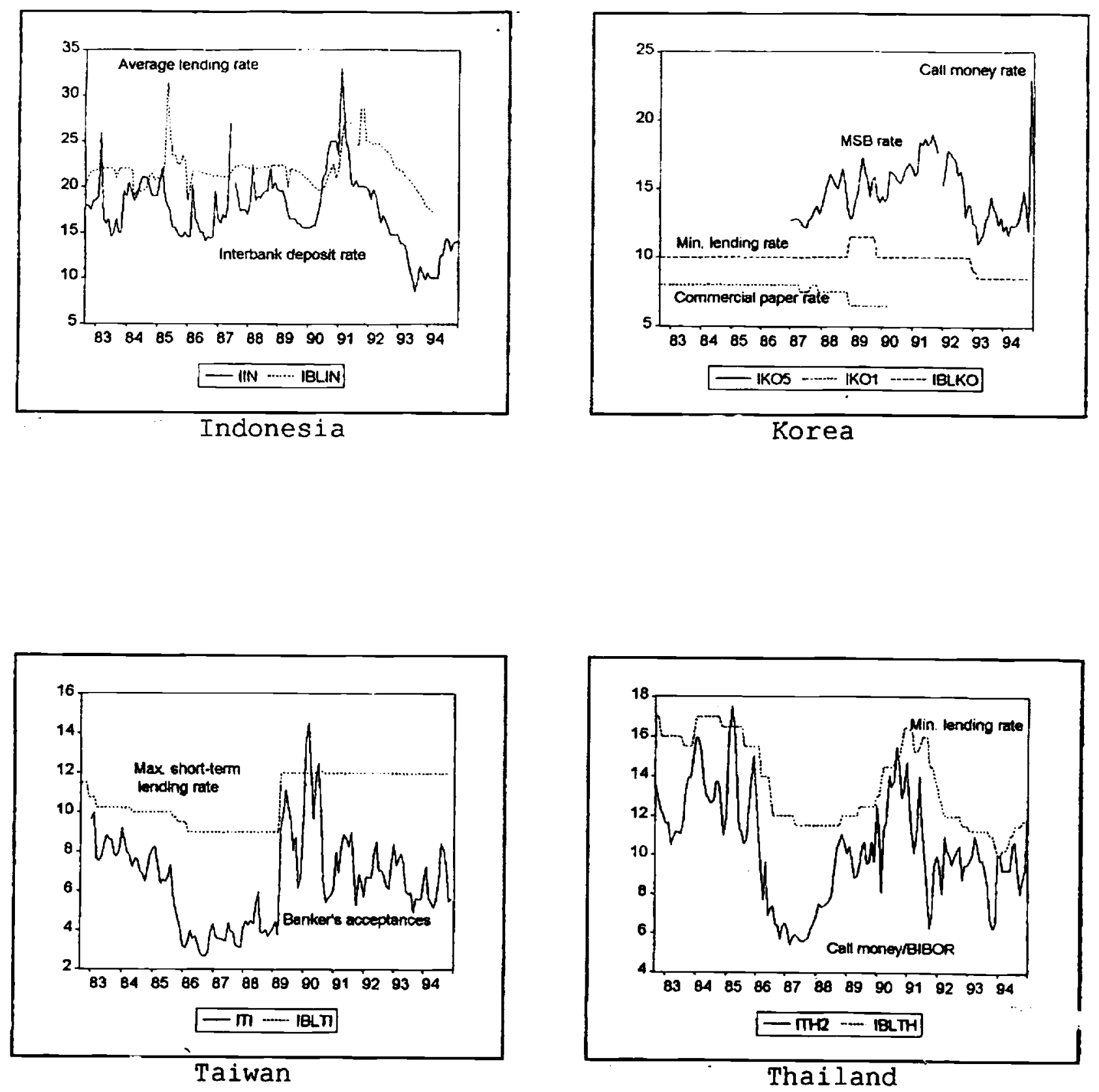
Figure 2 (cont.)
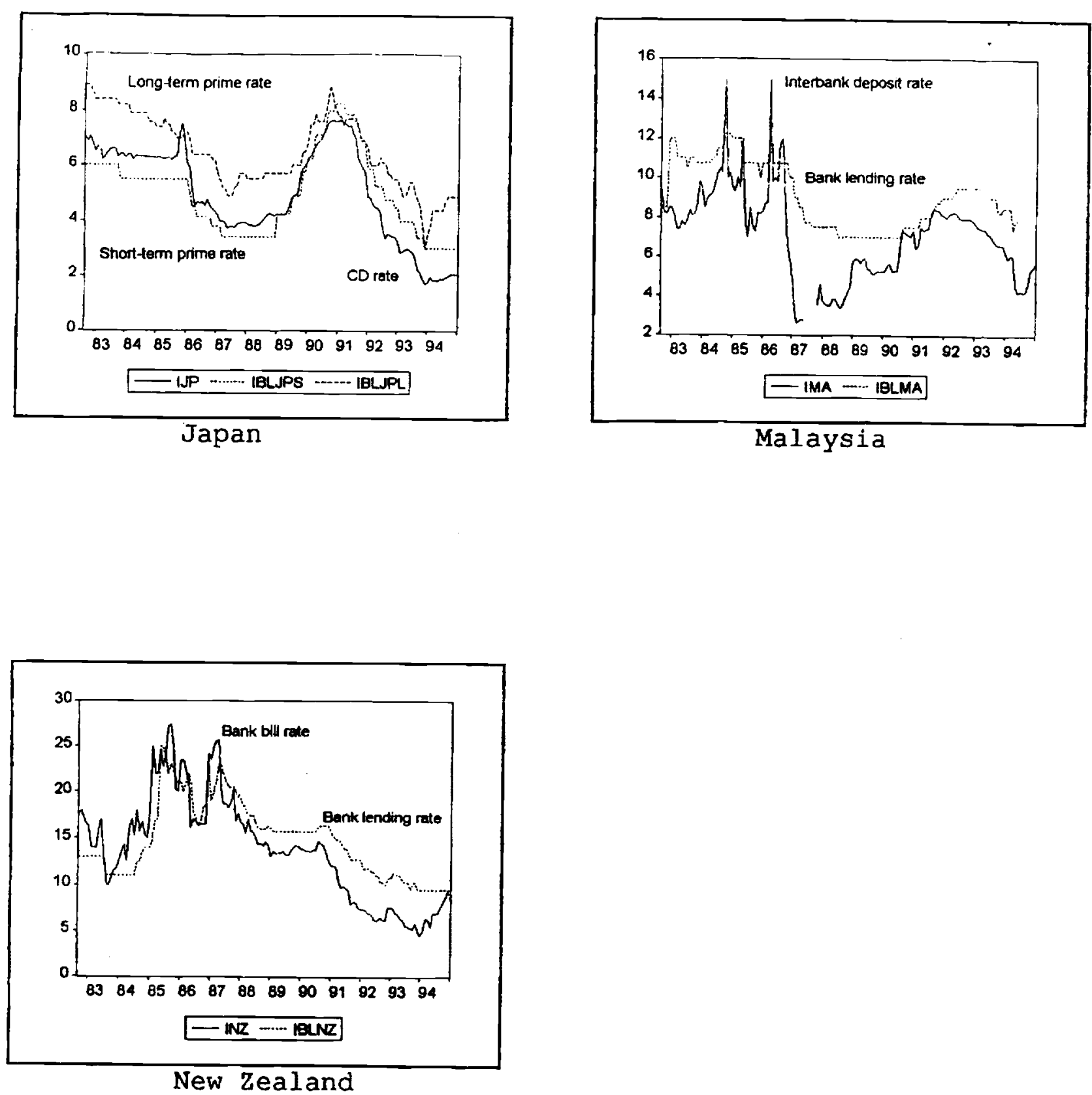
Table 1

Covered Interest Differentials

\begin{tabular}{lllll}
\hline & Mean & $\begin{array}{c}1982: 09-88: 04 \\
\text { Mean Abs. }\end{array}$ & Mean & $\begin{array}{c}1988: 05-94: 11 \\
\text { Mean Abs. }\end{array}$ \\
Australia & -0.20 & 0.88 & 0.27 & 0.29 \\
Canada & -0.01 & 0.16 & 0.10 & 0.22 \\
Hong Kong & 0.11 & 0.20 & 0.14 & 0.17 \\
Japana & 0.08 & 0.14 & 0.01 & 0.05 \\
Malaysia & -1.41 & 1.51 & -0.01 & 1.28 \\
New Zealand & -0.49 & 1.63 & 0.27 & 0.30 \\
Singapore & -0.47 & 0.49 & -0.91 & 0.91 \\
\hline
\end{tabular}

Notes: Figures in percentage points, estimated by regressing the end-of-month covered interest differential on a constant.

- CD-Euroyen differential. Data up to 1986:09 is Gensaki rate.

Estimate is from a regression with a dummy for Gensaki series, so that the differential is interpretable as that pertaining to a $C D$ rate. 
Table 2

Interest Differentials

(in percentage points)

\begin{tabular}{|c|c|c|c|c|}
\hline & Mean & $\begin{array}{l}09-88: 04 \\
\text { Mean Abs. }\end{array}$ & Mean & $\begin{array}{l}: 05-94: 11 \\
\text { Mean Abs. }\end{array}$ \\
\hline Australia & 5.40 & 5.47 & 4.20 & 4.20 \\
\hline Canada & 1.16 & 1.27 & 2.57 & 2.57 \\
\hline Hong Kong & -0.64 & 1.57 & 0.28 & 0.38 \\
\hline Indonesia & 9.24 & 9.24 & 10.94 & 10.94 \\
\hline Japan & -2.90 & 2.90 & -1.17 & 1.80 \\
\hline Korea & 6.27 & 6.27 & 8.95 & 8.95 \\
\hline Malaysia & -0.51 & 2.13 & 0.20 & 2.99 \\
\hline New Zealand & 9.63 & 9.64 & 3.90 & 3.90 \\
\hline Philippines & 10.47 & 10.47 & 11.08 & 11.08 \\
\hline Singapore & -2.62 & 2.62 & -2.02 & 2.022 \\
\hline Taiwan & -2.64 & 2.69 & 1.04 & 2.74 \\
\hline Thailand & 2.05 & 2.51 & 4.05 & 4.13 \\
\hline
\end{tabular}

Notes: Figures in percentage points, obtained by regressing the local minus US Eurodollar interest differentials on a constant. 
Table3 Average Bank Reserve Ratios

\begin{tabular}{|c|c|c|c|c|c|c|c|c|}
\hline Year & USA & Japan & Korea & Indonesia & Malaysia & Philippin & Singapore & Thailand \\
\hline 1986 & 0.03147 & 0.01390 & 0.10164 & 0.09058 & 0.06134 & 0.10301 & 0.04020 & 0.04442 \\
\hline 1987 & 0.02729 & 0.01312 & 0.10217 & 0.08865 & 0.06185 & 0.09802 & 0.03834 & 0.05401 \\
\hline 1988 & 0.02555 & 0.01467 & 0.10585 & 029 & 0.06275 & 0.09519 & 93 & 0.04792 \\
\hline 1989 & 0.02376 & 0.01288 & 0.09504 & 0.07893 & 0.08885 & 0.11852 & 878 & 0.04325 \\
\hline 1990 & 0.02506 & 0.01582 & 0.07502 & 0.04665 & 0. 12106 & 0.10930 & 0.03837 & 0.03488 \\
\hline 1991 & 0.02148 & 0.01377 & 0.08000 & 0.10260 & 0.12659 & 0.12790 & 0.04424 & 0.03701 \\
\hline 1992 & 0.02125 & 0.01118 & 0.08668 & 0.11274 & 0.10732 & 0.13116 & 0.04358 & 0.02985 \\
\hline 1993 & 0.02204 & 0.01124 & 0.08726 & n. a. & 0.09388 & 0.12856 & 0.04399 & 0.02984 \\
\hline an & 0.02474 & 0.01332 & 0.09171 & 0.08864 & 0.09045 & 0.11396 & 0.04093 & 0.04015 \\
\hline
\end{tabular}


Table 4

Response of Imports to Bank Credit or Money

$$
\begin{aligned}
& \Delta \text { imports }_{t}=\eta_{0}+\sum_{i=1}^{k} \eta_{i} \Delta b c_{t-i}+\sum_{i=1}^{k} \beta i \Delta q_{t-i}+\sum_{i=1}^{k} \gamma_{i} \Delta y_{t-i}+e_{t} \\
& \Delta \text { imports }_{t}=v_{0}+\sum_{i=1}^{k} v_{i} \Delta m I_{t-i}+\sum_{i=1}^{k} \beta \Delta q_{t-i}+\sum_{i=1}^{k} \gamma_{i} \Delta y_{t-i}+e_{t}
\end{aligned}
$$

\begin{tabular}{|c|c|c|c|c|c|c|c|}
\hline Country & $\Sigma_{1} \eta_{1}$ & $\Sigma_{i} v_{i}$ & $\mathbf{k}$ & $\bar{R}^{2}$ & $\mathrm{LM}(4)$ & $\mathbf{N}$ & Sample \\
\hline Australia & \multicolumn{2}{|c|}{$\begin{array}{l}-0.530 \\
{[.224]}\end{array}$} & 5 & 0.45 & $\begin{array}{l}1.383 \\
{[0.264]}\end{array}$ & 52 & $81 \cdot 3-94 \cdot 2$ \\
\hline Australia & & $\begin{array}{l}0.711 \\
{[0.105]}\end{array}$ & 4 & 0.53 & $\begin{array}{l}1.336 \\
{[0.277]}\end{array}$ & 53 & $81.2-94.2$ \\
\hline Canada & \multicolumn{2}{|c|}{$\begin{array}{l}-1.256 \star \star \\
{[0.023]}\end{array}$} & 4 & 0.72 & $\begin{array}{l}0.254 \\
{[0.905]}\end{array}$ & 53 & $81.2-94.2$ \\
\hline Canada & & $\begin{array}{l}0.229 \\
{[0.585]}\end{array}$ & 4 & 0.61 & $\begin{array}{l}0.865 \\
{[0.495]}\end{array}$ & 54 & $81 \cdot 2-94 \cdot 3$ \\
\hline Indonesia $^{c}$ & \multicolumn{2}{|c|}{$\begin{array}{l}0.595 \\
{[0.214]}\end{array}$} & 4 & -.12 & $\begin{array}{l}0.302 \\
{[0.874]}\end{array}$ & 49 & $81 \cdot 2-93 \cdot 2$ \\
\hline Indonesia ${ }^{c}$ & & $\begin{array}{l}0.998 * * \\
{[0.027]}\end{array}$ & 4 & 0.27 & $\begin{array}{l}1.546 \\
{[0.223]}\end{array}$ & 49 & $81.2-93.2$ \\
\hline Japan & \multicolumn{2}{|c|}{$\begin{array}{l}3.667 \star \star \star \\
{[0.009]}\end{array}$} & 4 & 0.19 & $\begin{array}{l}1.973 \\
{[0.123]}\end{array}$ & 51 & $81 \cdot 2-93 \cdot 4$ \\
\hline Japan & & $\begin{array}{l}0.885 \\
{[0.462]}\end{array}$ & 6 & 0.26 & $\begin{array}{l}1.681 \\
{[0.770]}\end{array}$ & 49 & $81.4-93.4$ \\
\hline Korea & \multicolumn{2}{|c|}{$\begin{array}{l}0.727 \\
{[0.275]}\end{array}$} & 4 & 0.57 & $\begin{array}{l}1.740 \\
{[0.165]}\end{array}$ & 53 & $81 \cdot 2-94.2$ \\
\hline Korea & & $\begin{array}{l}0.010 \\
{[0.964]}\end{array}$ & 4 & 0.55 & $\begin{array}{l}1.544 \\
{[0.212]}\end{array}$ & 53 & $81.2-94.2$ \\
\hline Malaysiaa,b,c & \multicolumn{2}{|c|}{$\begin{array}{l}-1.506 \\
{[.123]}\end{array}$} & 5 & 0.11 & $\begin{array}{l}0.242 \\
{[0.912]}\end{array}$ & 46 & $82 \cdot 3-94 \cdot 3$ \\
\hline Malaysia, & & $\begin{array}{l}1.554 \\
{[0.237]}\end{array}$ & 5 & 0.12 & $\begin{array}{l}0.188 \\
{[0.247]}\end{array}$ & 46 & $82.3-94.3$ \\
\hline
\end{tabular}


Table 4 (cont.)

\begin{tabular}{|c|c|c|c|c|c|c|c|}
\hline Country & $\Sigma_{1} \alpha_{1}$ & $\Sigma_{1} \tau_{1}$ & $\mathbf{k}$ & $\overline{\mathrm{R}}^{2}$ & $\operatorname{LM}(4)$ & $\mathbf{N}$ & Sample \\
\hline $\begin{array}{l}\text { New } \\
\text { Zealand }\end{array}$ & \multicolumn{2}{|c|}{$\begin{array}{l}-0.580 \\
{[0.178]}\end{array}$} & 4 & 0.51 & $\begin{array}{l}1.513 \\
{[0.256]}\end{array}$ & 33 & $86.2-94.2$ \\
\hline $\begin{array}{l}\text { New } \\
\text { Zealand }\end{array}$ & \multicolumn{3}{|c|}{$\begin{array}{l}0.142 \\
{[0.569]}\end{array}$} & \multicolumn{3}{|c|}{$[0.343]$} & $86.2-94.2$ \\
\hline $\begin{array}{l}\text { Philip- } \\
\text { pines }\end{array}$ & \multicolumn{2}{|c|}{$\begin{array}{l}4.679 * \star \\
{[0.031]}\end{array}$} & 5 & 0.94 & $\begin{array}{l}1.310 \\
{[0.859]}\end{array}$ & 20 & $89.2-94.1$ \\
\hline $\begin{array}{l}\text { Philip- } \\
\text { pines }\end{array}$ & & $\begin{array}{l}-0.655 \\
{[0.878]}\end{array}$ & 5 & -.46 & $\begin{array}{l}2.620 \\
{[0.623]}\end{array}$ & 20 & $89.2-94.1$ \\
\hline Singapore ${ }^{\circ}$ & \multicolumn{2}{|c|}{$\begin{array}{l}-1.553 \\
{[0.120]}\end{array}$} & 4 & 0.26 & $\begin{array}{l}1.179 \\
{[0.360]}\end{array}$ & 35 & $85.4-94.1$ \\
\hline Singapore $^{c}$ & & $\begin{array}{l}1.921 \star \star \\
{[0.017]}\end{array}$ & 4 & 0.36 & $\begin{array}{l}0.590 \\
{[0.675]}\end{array}$ & 35 & $85.4-94.1$ \\
\hline Taiwan & \multicolumn{2}{|c|}{$\begin{array}{l}-0.788 \\
{[0.246]}\end{array}$} & 4 & 0.34 & $\begin{array}{l}1.185 \\
{[0.353]}\end{array}$ & 37 & $83.2-92.2$ \\
\hline Taiwan & & $\begin{array}{l}0.415 \\
{[0.453]}\end{array}$ & 4 & 0.26 & $\begin{array}{l}1.167 \\
{[0.360]}\end{array}$ & 37 & $84.1-92.2$ \\
\hline
\end{tabular}

Notes: Coefficients can be interpreted as elasticities. $*(* \star)[* \star \star]$ denotes significance at the $10 \%(5 \%)$ [1\%] marginal significance level according to an $F$-test for the null that $\Sigma \alpha_{1}=0$ [p-values in brackets]. $k$ is the number of lags in the regression. LM $F$ (4) is the $F$ version of the Breusch-Godfrey LM test for serial correlation of order 4 [p-values in brackets].

- Estimated using a filter of $(1-L)\left(1-L^{4}\right)$.

- Estimated using total domestic credit extended to private sector (IFS line 32d).

- All variables deflated using CPI. 
Table 5

Response of Output to Bank Credit or Money

$$
\begin{aligned}
& \Delta y_{t}=\alpha_{0}+\sum_{i=1}^{k} \alpha_{i} \Delta b c_{t-i}+\sum_{i=1}^{k} \beta_{i} \Delta q_{t-i}+\sum_{i=1}^{k} \gamma_{i} \Delta y_{t-i}+e_{t} \\
& \Delta y_{t}=\tau_{0}+\sum_{i=1}^{k} \tau_{i} \Delta m 1_{t-i}+\sum_{i=1}^{k} \beta \Delta q_{t-i}+\sum_{i=1}^{k} \gamma_{i} \Delta y_{t-i}+e_{t}
\end{aligned}
$$

\begin{tabular}{|c|c|c|c|c|c|c|c|}
\hline country & $\Sigma_{1} \alpha_{1}$ & $\Sigma_{1} \tau_{1}$ & $\mathbf{k}$ & $\overline{\mathbf{R}}^{2}$ & $\operatorname{LM}(4)$ & $\mathbf{N}$ & Sample \\
\hline Australia & \multicolumn{2}{|c|}{$\begin{array}{l}-0.087 \\
{[.356]}\end{array}$} & 6 & -.02 & $\begin{array}{l}0.851 \\
{[0.095]}\end{array}$ & 52 & $81.4-94.3$ \\
\hline Australia & & $\begin{array}{l}0.173 * \\
{[0.525]}\end{array}$ & 4 & 0.11 & $\begin{array}{l}4.028 \\
{[0.402]}\end{array}$ & 54 & $82 \cdot 1-94 \cdot 3$ \\
\hline Canada & \multicolumn{2}{|c|}{$\begin{array}{l}-0.462 * * * \\
{[0.000]}\end{array}$} & 4 & 0.26 & $\begin{array}{l}1.052 \\
{[0.902]}\end{array}$ & 53 & $81 \cdot 2-94 \cdot 2$ \\
\hline Canada & & $\begin{array}{l}0.224 * * * \\
{[0.000]}\end{array}$ & 4 & 0.09 & $\begin{array}{l}1.889 \\
{[0.756]}\end{array}$ & 54 & $81 \cdot 2-94.2$ \\
\hline Japan & \multicolumn{2}{|c|}{$\begin{array}{l}0.487 * \star \star \\
{[0.003]}\end{array}$} & 4 & 0.25 & $\begin{array}{l}2.983 \\
{[0.561]}\end{array}$ & 51 & $81 \cdot 2-93 \cdot 4$ \\
\hline Japan & & $\begin{array}{l}0.110 \\
{[0.420]}\end{array}$ & 4 & 0.10 & $\begin{array}{l}1.703 \\
{[0.770]}\end{array}$ & 51 & $81.2-93 \cdot 4$ \\
\hline Korea" & \multicolumn{2}{|c|}{$\begin{array}{l}0.090 \\
{[0.867]}\end{array}$} & 4 & 0.41 & $\begin{array}{l}6.643 \\
{[0.156]}\end{array}$ & 47 & $83.1-94.3$ \\
\hline Korea" & \multicolumn{2}{|r|}{$\begin{array}{l}0.028 \\
{[0.869]}\end{array}$} & 4 & 0.38 & \multicolumn{2}{|c|}{$[0.062]$} & $83.1-94.3$ \\
\hline $\begin{array}{l}\text { New } \\
\text { Zeal and }\end{array}$ & \multicolumn{2}{|c|}{$\begin{array}{l}-0.121 \\
{[0.370]}\end{array}$} & 2 & 0.20 & $\begin{array}{l}4.409 \\
{[0.354]}\end{array}$ & 36 & $85.4-94.3$ \\
\hline $\begin{array}{l}\text { New } \\
\text { Zealand }\end{array}$ & & $\begin{array}{l}0.022 \\
{[0.780]}\end{array}$ & 2 & 0.20 & $\begin{array}{l}4.290 \\
{[0.368]}\end{array}$ & 36 & $85.4-94.3$ \\
\hline $\begin{array}{l}\text { Philip- } \\
\text { pines }\end{array}$ & \multicolumn{2}{|c|}{$\begin{array}{l}0.088 \\
{[0.331]}\end{array}$} & 2 & 0.98 & $\begin{array}{l}0.628 \\
{[0.428]}\end{array}$ & 29 & $87.3-94.3$ \\
\hline $\begin{array}{l}\text { Philip- } \\
\text { pines }\end{array}$ & & $\begin{array}{l}0.060 \\
{[0.859]}\end{array}$ & 4 & 0.98 & 2.814 & $\begin{array}{r}27 \\
39]\end{array}$ & $88 \cdot 1-94 \cdot 3$ \\
\hline
\end{tabular}




\begin{tabular}{|c|c|c|c|c|c|c|c|}
\hline country & $\Sigma_{1} \alpha_{1}$ & $\Sigma_{1} \tau_{1}$ & $\mathbf{k}$ & $\overline{\mathbf{R}}^{2}$ & $\operatorname{LM}(4)$ & $\mathbf{N}$ & Sample \\
\hline Singapore & \multicolumn{2}{|c|}{$\begin{array}{l}-0.164 \\
{[0.254]}\end{array}$} & 3 & 0.93 & $\begin{array}{l}6.822 \\
{[0.146]}\end{array}$ & 35 & $85.3-94.1$ \\
\hline Singapore & & $\begin{array}{l}0.035 \\
{[0.654]}\end{array}$ & 1 & 0.87 & $\begin{array}{l}2.814 \\
{[0.589]}\end{array}$ & 37 & $85.1-94.1$ \\
\hline Taiwan & \multicolumn{2}{|c|}{$\begin{array}{l}-0.025 \\
{[0.499]}\end{array}$} & 2 & 0.61 & $\begin{array}{l}7.601 \\
{[0.107]}\end{array}$ & 36 & $83.3-92.2$ \\
\hline Taiwan ${ }^{\mathrm{b}}$ & & $\begin{array}{l}0.045 \\
{[0.448]}\end{array}$ & 4 & 0.79 & $\begin{array}{l}7.076 \\
{[0.132]}\end{array}$ & 34 & $84.1-92.2$ \\
\hline
\end{tabular}

Notes: Coefficients can be interpreted as elasticities. $*(* *)[* * *]$ denotes significance at the $10 \%(5 \%)$ [1\%] marginal significance level according to an F-test for the null that $\Sigma \alpha_{1}=0$ [p-values in brackets]. $k$ is the number of lags in the regression. LM(4) is the Breusch-Godfrey LM test for serial correlation of order 4 [p-values in brackets].

- Estimated using a filter of $\left(1-L^{4}\right)(1-L)$.

- Estimated using a filter of $\left(1-L^{4}\right)$. 
Table 6

Response of Investment to Bank Credit or Money

$$
\begin{aligned}
& \Delta i n v_{t}=\theta_{0}+\sum_{i=1}^{k} \theta_{i} \Delta b c_{t-i}+\sum_{i=1}^{k} \phi_{i} y_{t-i}+\sum_{i=1}^{k} \eta_{i} q_{t-i}+w_{t} \\
& \Delta i n v_{t}=\theta_{0}+\sum_{i=1}^{k} \theta_{i} \Delta m 1_{t-i}+\sum_{i=1}^{k} \phi_{i} y_{t-i}+\sum_{i=1}^{k} \eta_{i} q_{t-i}+w_{t}
\end{aligned}
$$

\begin{tabular}{|c|c|c|c|c|c|c|c|}
\hline country & $\Sigma_{1} \theta_{1}$ & $\Sigma_{1} \theta_{1}$ & $\mathrm{k}$ & $\overline{\mathbf{R}}^{2}$ & $\operatorname{LM}(4)$ & $\mathbf{N}$ & Sample \\
\hline Australia & \multicolumn{2}{|c|}{$\begin{array}{l}-0.267 \\
{[.356]}\end{array}$} & 4 & 0.04 & $\begin{array}{l}6.679 \\
{[0.154]}\end{array}$ & 54 & $81 \cdot 2-94 \cdot 3$ \\
\hline Australia & & $\begin{array}{l}0.438 * \\
{[0.060]}\end{array}$ & 4 & 0.27 & $\begin{array}{l}7.478 \\
{[0.113]}\end{array}$ & 54 & $81 \cdot 2-94 \cdot 3$ \\
\hline Canada & \multicolumn{2}{|c|}{$\begin{array}{l}-0.499 \\
{[0.169]}\end{array}$} & 4 & 0.22 & $\begin{array}{l}5.339 \\
{[0.254]}\end{array}$ & 53 & $81 \cdot 2-94 \cdot 2$ \\
\hline Canada & & $\begin{array}{l}0.509 * * \\
{[0.016]}\end{array}$ & 4 & 0.29 & $\begin{array}{l}7.987 \\
{[0.092]}\end{array}$ & 54 & $81 \cdot 2-94 \cdot 2$ \\
\hline Japan & \multicolumn{2}{|c|}{$\begin{array}{l}1.505 * * * \\
{[0.000]}\end{array}$} & 4 & 0.46 & $\begin{array}{l}2.168 \\
{[0.705]}\end{array}$ & 51 & $81 \cdot 2-93 \cdot 4$ \\
\hline Japan & & $\begin{array}{l}0.452 \\
{[0.109]}\end{array}$ & 4 & 0.18 & $\begin{array}{l}7.537 \\
{[0.110]}\end{array}$ & 51 & $81 \cdot 2-93 \cdot 4$ \\
\hline Korea" & \multicolumn{2}{|c|}{$\begin{array}{l}0.269 \\
{[0.796]}\end{array}$} & 4 & -.02 & $\begin{array}{l}6.635 \\
{[0.157]}\end{array}$ & 46 & $83.1-94.2$ \\
\hline Korea & & $\begin{array}{l}-0.048 \\
{[0.869]}\end{array}$ & 4 & 0.09 & $\begin{array}{l}3.697 \\
{[0.449]}\end{array}$ & 46 & $83.1-94.2$ \\
\hline
\end{tabular}

Notes: Coefficients can be interpreted as elasticities. $*(* \star)[* \star *]$ denotes significance at the 10\%(5\%)[1\%] marginal significance level according to an $F$-test for the null that $\Sigma_{1} \theta_{1}=0$ or $\Sigma_{1} \theta_{1}=0$ [pvalues in brackets]. $k$ is the number of lags in the regression. LM(4) is the Breusch-Godfrey LM test for serial correlation of order 4 [p-values in brackets].

- Estimated using a filter of $\left(1-L^{4}\right)(1-L)$. 